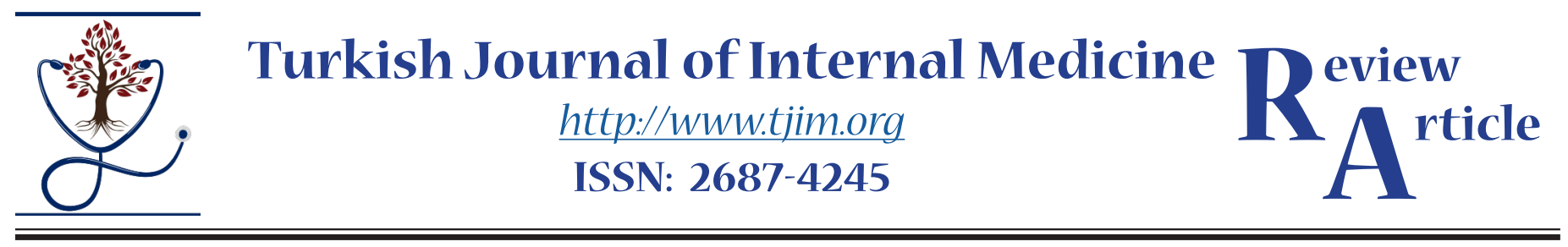

\title{
Viewpoint of COVID-19 in Africa and Latin America
}

\author{
Ernest Herbert ${ }^{1}$ (D), Dominique Fournier ${ }^{2}$ (iD) \\ ${ }^{1}$ Ashfield Healthcare Ltd, UK \\ ${ }^{2}$ IUCPQ-UL, Canada
}

\begin{abstract}
The spread of COVID-19 across the African continent and Latin American region is of great concern due to several influencing factors. Large and densely populated areas and townships with widespread poverty and high migration are the most vulnerable populations for a pandemic of this magnitude. The latter could be complicated since known communicable diseases such as chronic obstructive pulmonary disease (COPD), diabetes, cardiovascular disorder, hypertension and lack of basic healthcare delivery systems are known risks that may enhance the degree of mortality, via the pandemic in affected regions. The aim of this review is to focus on the clinical signs, transmission, case fatalities and influencing factors that might exacerbate the pandemic in these regions.
\end{abstract}

Turk J Int Med 2020;2(4): 98-104 DOI: $\underline{10.46310 / \text { tjim. } 768866}$

Keywords: COVID-19, Government regulation, Signs, Transmission, Fatalities

\section{Introduction}

Since December 31, 2019, when the outbreak began in China, and as of July 9, 2020, there are $\sim 12 \mathrm{M}$ cases and over $\sim 550,000$ deaths worldwide in more than 213 countries. In Africa, those reporting most cases (Table 1) are from South Africa (224,665), Egypt (78,304), Nigeria $(30,249)$, Ghana $(22,822)$ and Algeria $(17,348)$, whereas $5 \mathrm{M}+$ cases are accounted in America comprising of the US ( 3M), Brazil $(1,668,589)$,
Peru $(309,278)$, Chile $(303,083)$ and Mexico $(268,008)$. The spread of COVID-19 is mainly through travellers. ${ }^{1,2}$ Although the virus emerged from China, the mostly affected countries include the US, Brazil, the UK, Italy, Spain, France, Iran, Germany and others to name but a few. ${ }^{1}$ COVID-19 is a broad spectrum of disease, starting from asymptomatic cases that may recover with no underlying symptoms, up to complicated 
Table 1. List of African countries with confirmed cases of COVID-19 \& Fatalities (Data adopted/modified from ${ }^{27}$ ) (As of July 9, 2020)

\begin{tabular}{|c|c|c|}
\hline Country & COVID-19 cases (n) & Fatalities (n) \\
\hline South Africa & 224,665 & 3,602 \\
\hline Nigeria & 30,249 & 684 \\
\hline Ghana & 22,822 & 129 \\
\hline Algeria & 17,348 & 978 \\
\hline Cameroon & 14,916 & 359 \\
\hline Côte d'Ivoire & 11,504 & 78 \\
\hline Senegal & 7,657 & 141 \\
\hline Democratic Republic of Congo & 7,736 & 183 \\
\hline Guinea & 5,697 & 34 \\
\hline Kenya & 8,528 & 169 \\
\hline Gabon & 5,871 & 46 \\
\hline Ethiopia & 6,973 & 120 \\
\hline Central African Republic & 4,109 & 52 \\
\hline Mauritania & 5,024 & 135 \\
\hline Mali & 2,358 & 120 \\
\hline South Sudan & 2,106 & 40 \\
\hline Guinea Bissau & 1,790 & 25 \\
\hline Madagascar & 3,573 & 33 \\
\hline Zambia & 1,895 & 42 \\
\hline Sierra Leone & 1,584 & 63 \\
\hline Equatorial Guinea & 1,043 & 12 \\
\hline Niger & 1,097 & 68 \\
\hline Burkina Faso & 1,003 & 53 \\
\hline Congo & 1,821 & 47 \\
\hline Chad & 873 & 74 \\
\hline Cabo Verde & 1,542 & 18 \\
\hline Uganda & 977 & 0 \\
\hline Sao Tome \& Principe & 404 & 11 \\
\hline Mozambique & 1,071 & 8 \\
\hline Rwanda & 1,194 & 3 \\
\hline Benin & 1,285 & 23 \\
\hline Malawi & 1,942 & 25 \\
\hline Eswatini & 1,138 & 14 \\
\hline Liberia & 926 & 41 \\
\hline Togo & 695 & 15 \\
\hline United Republic of Tanzania & 509 & 21 \\
\hline Zimbabwe & 885 & 9 \\
\hline Mauritius & 342 & 10 \\
\hline Comoros & 313 & 7 \\
\hline Angola & 396 & 22 \\
\hline Eritrea & 215 & 0 \\
\hline Burundi & 219 & 1 \\
\hline Botswana & 314 & 1 \\
\hline Namibia & 593 & 0 \\
\hline Gambia & 63 & 3 \\
\hline Seychelles & 94 & 0 \\
\hline Lesotho & 134 & 1 \\
\hline Egypt & 78,304 & 3,564 \\
\hline
\end{tabular}


severe, life-threatening and even fatalities, perhaps leading to unknown non-acute effects, still to be better defined. ${ }^{3}$

There has been rapid response to the pandemic from public health authorities in Africa well ahead of reported cases which sounds encouraging action in fighting against it. ${ }^{4}$ The African Centres for Disease Control and Prevention Task Force was inaugurated on February 3, 2020, for this pandemic. ${ }^{4}$ It works in collaboration with the World Health Organisation (WHO) Regional Office for Africa on community engagement, surveillance, screening at points of entry, infection prevention and control in healthcare settings, clinical management of patients with severe COVID-19 infection, laboratory diagnosis, and risk communication. ${ }^{5}$ Most nations in Africa have set up measures to the current COVID-19 pandemic. These efforts are not without challenges. The major ones range from lacking well-established and functional health centres up to village levels, tribal sentiments, religious and most importantly, unaccountable corrupt governments across the continent for decades. These are not bothered about using the resources at their disposal in providing basic amenities such as hospitals, education, healthcare centres, roads, electricity, water, as well as housing and improve health-related quality of life. This sort of governance is a general malaise that had engulfed the 54 nations of Africa, with the exception of Ghana, recently trying to change its trajectory prior to the pandemic. The fundamental question now is what lessons could be learnt from this pandemic? Will the leaders of the countries in Africa modify their course of governance to be accountable, prudent and use the resources to the benefit of the poor masses? Or will it continue to be business as usual in enriching themselves as has been the cases for the past decades pre-COVID-19 or a drastic change for good after this?

According to the report from the World Economic Forum 2020, Africa has the lowest capacity to provide critical and intensive care in the world. ${ }^{6}$ Social and religious gatherings are not uncommon in Africa. ${ }^{4}$ Many countries have banned such meetings, and this has received resistance from some people across the region thus affecting physical distancing. Family clusters, low health literacy, "infodemic" and poverty may contribute to poor response. ${ }^{4}$ The lockdowns and stay-at-home strategy working have halted business activities, making the poorer the most vulnerable to the economic consequences, posing further difficulties to adhere to precautionary measures. Price hikes for masks and hand sanitizers have also been reported. ${ }^{4}$

Since the start of the outbreak, the WHO has been supporting African governments with early detection by providing thousands of COVID-19 testing kits to countries, training dozens of health workers and strengthening surveillance in communities. ${ }^{4}$ So 44 countries in the WHO African region can now test for COVID-19. ${ }^{4}$ At the beginning of the outbreak, only two of them could do so which is a testimony of the style they govern across the continent and lack of basic healthcare facilities available to the populace.

From February 25, 2020, when COVID-19 was confirmed for the first time in Brazil, while someone was coming from Italy, up to July 9, $2020,3.1 \mathrm{M}+$ cases with $\sim 133,000$ deaths have been reported in Latin America and Caribbean region, and this country is still leading the way with $\sim 1.7 \mathrm{M}$ cases and greater than 66,000 deaths respectively. ${ }^{7,8}$ In a complex pandemic like COVID-19, the epidemiological situation in Latin America before February 25, 2020, was already intricate, with other overlapping epidemics of varying vector-borne pathogens such as dengue and yellow fever, but also struggling from the long-term endemic consequences after 2014-2016 outbreaks of chikungunya and Zika. ${ }^{3,9}$

Latin America was the last significant region where COVID-19 arrived. ${ }^{3}$ The healthcare systems in Latin America are fragile coupled with fragmentation and segmentation, which are continuing challenges facing these vulnerable systems. ${ }^{10}$ There are multiple ongoing social and economic problems, so COVID-19 pandemic will have tremendous impact on, including the massive exodus of people from Venezuela to many countries in the region. This human migration is associated with other pathogenic diseases, such as malaria or measles. ${ }^{3}$

In Latin America, there is a large heterogeneity of political, social development, and economic growth capacities. For instance, in the Caribbean sub-region, countries such as Haiti have a low human development index, while in Venezuela, ongoing humanitarian crisis exists and the impact of COVID-19 will be more devastating there than those with more developed economies like Brazil 
Table 2. List of Latin American countries with confirmed cases of COVID-19 \& Fatalities (Data adopted/modified from ${ }^{28}$ ) (As of July 9, 2020)

\begin{tabular}{|c|c|c|}
\hline Country & CoVID-19 cases (n) & Fatalities (n) \\
\hline Brazil & $1,668,589$ & 66,741 \\
\hline Peru & 309,278 & 10,952 \\
\hline Mexico & 268,008 & 32,014 \\
\hline Bolivia (Plurinational State of) & 41,545 & 1,530 \\
\hline Chile & 303,083 & 6,573 \\
\hline Argentina & 83,426 & 1,654 \\
\hline Paraguay & 2,554 & 20 \\
\hline Uruguay & 965 & 29 \\
\hline Antigua \& Barbuda & 70 & 3 \\
\hline Barbados & 98 & 7 \\
\hline El Salvador & 8,566 & 235 \\
\hline Ecuador & 63,245 & 4,873 \\
\hline Bahamas & 104 & 11 \\
\hline Cayman Islands & 201 & 1 \\
\hline Jamaica & 745 & 10 \\
\hline Cuba & 2,399 & 86 \\
\hline Suriname & 635 & 17 \\
\hline Guatemala & 24,787 & 1,004 \\
\hline Belize & 30 & 2 \\
\hline Honduras & 25,428 & 677 \\
\hline Nicaragua & 2,411 & 91 \\
\hline Guyana & 284 & 16 \\
\hline French Guiana & 5,459 & 22 \\
\hline Martinique & 249 & 14 \\
\hline Saint Vincent \& The Grenadines & 29 & 0 \\
\hline Trinidad \& Tobago & 133 & 8 \\
\hline Dominican Republic & 39,588 & 829 \\
\hline Haiti & 6,432 & 117 \\
\hline Venezuela (Bolivarian Republic of) & 7,693 & 71 \\
\hline Aruba & 105 & 3 \\
\hline Colombia & 124,494 & 4,359 \\
\hline Costa Rica & 5,486 & 23 \\
\hline Panama & 40,291 & 799 \\
\hline Bermuda & 149 & 9 \\
\hline Falkland Islands & 13 & 0 \\
\hline Saint Lucia & 22 & 0 \\
\hline
\end{tabular}

or Mexico. ${ }^{3}$ Incidentally, the largest Latin America country is second in ranking behind the US in terms of infected cases and corresponding fatalities with COVID-19, Jair Bolsonaro's government has been strongly criticised for the utter confusion and guidance in handling the outbreak among 210 million Brazilians (Table 2). The disarray in the heart of administration is a deadly distraction at the core of a public health emergency and is also a stark indicator that Brazil's leadership has lost its moral navigation. ${ }^{11}$

\section{Clinical Signs}

The major symptoms associated with COVID-19 include fever, cough, fatigue, myalgia, arthralgia and dyspnea, which could eventually lead to respiratory failure. ${ }^{12}$ They could also be preceded by nonrespiratory ones such as diarrhea, abdominal pain, palpitations, dizziness and headaches. However, some of these could manifest during the period of isolation. Though the mechanism surrounding 
olfactory impairment with COVID-19 is not fully understood, ageusia and anosmia might be among the first line of symptoms. COVID-19 is weird in its clinical behaviour and could be variable.

Asymptomatic individuals though do not exhibit any of COVID-19 symptoms nor aware of the infection, but have the capability of transmitting to other people from their faeces if not tested and isolated. It has been noticed that some patients who suffered from COVID-19 recovered without antibodies and it is not always those that are found after being cured. ${ }^{13}$

The clinical signs of COVID-19 could overlap with that of malaria or any other comorbidity and complicate diagnosis especially in the rural and suburban towns in Africa. Strangely, many millions of individuals in this region and possibly in Latin America had never received any medical attention all their lives, may even have COVID-19 and get it confused with malaria. In such localities, mass testing, contact tracing, isolation, educating people on the principle of protecting themselves as well as others will play major roles in combating the infection among such individuals. For the limited available health centres or hospitals, many inhabitants have to travel long distances to access them.

\section{Transmission of COVID-19 in Africa \& Latin America and the Caribbean}

The countries in Africa, Latin America and Caribbean (LAC) share common problems where water scarcity and poor sanitation may substantially impact on the spread of COVID-19. ${ }^{5}$ The World Bank estimates that 36 million people in LAC lack access to potable drinking water, and 110 million do not have access to improved sanitation. ${ }^{5}$ In urban slums where there is no inhome water filtration, results in reduced usage, limited handwashing facilities, and poor family hygiene, leading to faecal contamination on a broad scale. ${ }^{14}$ In households without clean pipeborne water system, drinking is often from boiled and stored sources; yet such water may be contaminated through faecal means as there is no form of treatment. ${ }^{14}$ Water shortages and delivery both in some urban and rural areas of LAC is replicated in most African countries as well. Importantly, coronaviruses can remain infectious for weeks in room temperature water. ${ }^{15}$ If there is an increased transmission caused by faecal contamination in combination with reducing contacts, the epidemiological dynamics of COVID-19 in LAC may be fundamentally distinct from that currently noticed in the Northern Hemisphere. ${ }^{16}$

Despite the fact that RNA from SARS-CoV-2 has been found in blood and stool specimens and it has also been cultured from faeces of some COVID-19 patients, faecal-oral transmission has not been taken as a vital mode of infection according to a report from WHO-China. ${ }^{17}$

The spread could be via direct means (droplet and human-to-human transmission) or indirect contact (contaminated objects and airborne contagion). Personal protective equipment (PPE) could also be the source of airborne infections. ${ }^{18}$ Person-to-person transmissions are mainly through respiratory droplets, when a patient coughs, sneezes, and even talks or sings. Typically, these cannot traverse more than almost two metres and remain in the air for a limited time. ${ }^{18}$ The ones containing the virus might contaminate surfaces such as smart phones up to a period of 96 hours. The SARS-CoV-2 can be suspended in the air for up to three hours and still be intact and contagious. ${ }^{19}$ Thus, airborne isolation precautions, room ventilation, and appropriate application of disinfectant (particularly in toilets) might minimise the aerosol spread of the virus. ${ }^{20}$

Asymptomatic individuals (or people within the incubation period) could transmit the virus even without any radiological symptoms. ${ }^{21-23}$ Although each patient had at least two negative tests among four hospital staff who tested positive, as their RTPCR results obtained from 5-13 days after being discharged. ${ }^{24}$

A study on semen and testicular samples of COVID-19 patients indicated that SARS-CoV-2 could not be transmitted via sexual contact. ${ }^{25}$

With a long incubation period for COVID-19, viral shedding in patients after recovery and presence of asymptomatic people, the rate of transmission could be controlled via education, isolation, preventive measures and treatment of infected individuals. ${ }^{26}$

\section{Conclusion}

The number of infected cases and fatalities 
associated with COVID-19 could be higher than expected as some of the health reporting could be wildly inconsistent and possibly politically controlled. This depends on individual country preparedness, available healthcare facilities and quality deliverance. Although the pandemic seemed to have taken the world by surprise, there were indications that this outbreak will happen but remained a question of when and by how much relative to impact.

With the situation in Brazil meanwhile, beyond this pandemic, it is a lesson for any other country or political leader whether in Africa or Latin America as the case may be that will be complacent over this crisis. It is an ongoing problem and remains a potential threat to the society, way of life and healthcare system at large.

Most of the inhabitants in Africa and some in Latin America have limited or no accesses to potable water both in urban and rural areas, which will impede compliance relative to frequent hand washing. Additionally, poor sanitation plus the fact that there are in most cases no health centres within the vicinity of the populace will definitely pose a high risk of contagion and treatment. Furthermore, will this pandemic change the mindset of some corrupt and unaccountable political leaders; this has been the case for decades while using their nations' resources to enhance qualities of lives in affected regions? What lessons can these leaders learn from COVID-19? Which way is to forward for the communities in terms of providing drinking-water quality, sanitation, healthcare, housing, electricity, education and transport network for both present and future generations to come?

Notably, there are millions of people in these regions with underlying health problems having no medical attention for years in their lives due to lack of adequate healthcare services. The health conditions of such individuals will be compounded with COVID-19 and could exacerbate the number of fatalities.

The pandemic has thrown the entire globe off balance including the developed nations. The impact is not only on healthcare along with more than half a million fatalities but is also the economic upheaval never seen before. Many businesses have gone burst and led off so many of their employees, talking less of African and Latin American regions where the hardship on people could even jump the roof. The health, economic and social impacts of COVID-19 could be minimised through appropriate lessons learnt such as running credible governance, provision of essential amenities and implementation of strategic practical measures to circumvent the crisis both today and in the future. Finally, well planned and coordinated logistical arrangements will have to be implemented from now onwards to every nook and corner of these continents to alleviate their inherent poverty and enhance their health-related quality of life.

Globally, the awareness and response to the pandemic are well known, but each country faces its strategies and scenarios in containing it based on resources and degree of preparedness.

\section{Conflict of Interests}

Authors declare that there are none.

\section{References}

1. World Health Organization. Coronavirus disease (COVID-19) - Situation Report - 57. Available at: https:// www.who.int/docs/default-source/coronaviruse/ situation-reports / 20200622 -covid-19-sitrep-154. pdf?sfvrsn=d0249d8d_2. Accessed June 30, 2020.

2. Rodríguez-Morales AJ, MacGregor K, Kanagarajah S, Patel D, Schlagenhauf P. Going global - Travel and the 2019 novel coronavirus. Travel Med Infect Dis. 2020 Jan-Feb;33:101578. doi: 10.1016/j.tmaid.2020.101578.

3. Rodriguez-Morales AJ, Gallego V, Escalera-Antezana JP, Méndez CA, Zambrano LI, Franco-Paredes C, Suárez JA, Rodriguez-Enciso HD, Balbin-Ramon GJ, Savio-Larriera E, Risquez A, Cimerman S. COVID-19 in Latin America: The implications of the first confirmed case in Brazil. Travel Med Infect Dis. 2020 May-Jun;35:101613. doi: 10.1016/j. tmaid.2020.101613.

4. Lucero-Prisno DE 3rd, Adebisi YA, Lin X. Current efforts and challenges facing responses to $2019-\mathrm{nCoV}$ in Africa. Glob Health Res Policy. 2020 May 6;5:21. doi: 10.1186/ s41256-020-00148-1.

5. Makoni M. Africa prepares for coronavirus. Lancet. 2020 Feb 15;395(10223):483. doi: 10.1016/S0140-6736(20)30355-X.

6. Kaseje N. Why Sub-Saharan Africa needs a unique response to Covid-19. Available at: https://www.weforum.org/ agenda/2020/03/why-sub-saharan-africa-needs-a-uniqueresponse-to-covid-19/. Accessed June 30, 2020.

7. Rodríguez-Morales AJ, Sánchez-Duque JA, HernándezBotero S, Pérez-Díaz CE, Villamil-Gómez WE, Méndez CA, Verbanaz S, Cimerman S, Rodriguez-Enciso HD, Escalera-Antezana JP, Balbin-Ramon GC, Arteaga-Livia FK, Cvetovikc-Vega A, Orduna T, Savio-Larrea E, PanizMondolfi A, en nombre de LANCOVID-19. Preparación y control de la enfermedad por Coronavirus 2019 (COVID-19) en América Latina. Acta Méd Peru. 2020 Mar 31;37(1):3-7. doi: 10.13140/RG.2.2.12356.78725.

8. Ríos AM. Latin America: COVID-19 deaths 2020, by country. 
Available at: https://www.statista.com/statistics/1103965/ latin-america-caribbean-coronavirus-deaths/. Accessed June 30, 2020.

9. Rodríguez-Morales AJ, Suárez JA, Risquez A, DelgadoNoguera L, Paniz-Mondolfi A. The current syndemic in Venezuela: Measles, malaria and more co-infections coupled with a breakdown of social and healthcare infrastructure. Quo vadis? Travel Med Infect Dis. 2019 Jan-Feb;27:5-8. doi: 10.1016/j.tmaid.2018.10.010.

10. The Lancet. The unfolding migrant crisis in Latin America. Lancet 2019; 394:1966. doi: 10.1016/S0140-6736 (19)32934-4.

11. The Lancet. COVID-19 in Brazil: "So what?". Lancet. 2020 May 9;395(10235):1461. doi: 10.1016/S0140-6736(20)31095-3.

12. Bagheri SH, Asghari A, Farhadi M, Shamshiri AR, Kabir A, Kamrava SK, Jalessi M, Mohebbi A, Alizadeh R, Honarmand AA, Ghalehbaghi B, Salimi A, Firouzabadi FD. Coincidence of COVID-19 epidemic and olfactory dysfunction outbreak in Iran. Med J Islam Repub Iran. 2020 Jun 15;34(1):446-52. doi: 10.34171/mjiri.34.62.

13. Wu F, Wang A, Liu M, Wang Q, Chen J, Xia S, Ling Y, Zhang Y, Xun J, Lu L, Jiang S, Lu H, Wen Y, Huang J. Neutralizing antibody responses to SARS-CoV-2 in a COVID-19 recovered patient cohort and their implications. medRxiv 2020. doi: 10.1101/2020.03.30.20047365.

14. Oswald WE, Hunter GC, Lescano AG, Cabrera L, Leontsini E, Pan WK, Soldan VP, Gilman RH. Direct observation of hygiene in a Peruvian shantytown: not enough handwashing and too little water. Trop Med Int Health. 2008 Nov;13(11):1421-8. doi: 10.1111/j.1365-3156.2008.02177.x.

15. Casanova L, Rutala WA, Weber DJ, Sobsey MD. Survival of surrogate coronaviruses in water. Water Res. 2009 Apr;43(7):1893-8. doi: 10.1016/j.watres.2009.02.002.

16. Miller MJ, Loaiza JR, Takyar A, Gilman RH. COVID-19 in Latin America: Novel transmission dynamics for a global pandemic? PLoS Negl Trop Dis. 2020 May 7;14(5):e0008265. doi: 10.1371/journal.pntd.0008265.

17. McKintosh, K. Coronavirus disease 2019 (COVID-19): Epidemiology, virology, and prevention. UpToDate 2020.

18. Water and Sanitory Program. Latin American and the Caribbean. 2018 March 25, 2020. Available at: https://www. wsp.org/content/latin-america-and-caribbean. Accessed June 30, 2020.

19. van Doremalen N, Bushmaker T, Morris DH, Holbrook MG, Gamble A, Williamson BN, Tamin A, Harcourt JL, Thornburg NJ, Gerber SI, Lloyd-Smith JO, de Wit E, Munster VJ. Aerosol and Surface Stability of SARS-CoV-2 as Compared with SARS-CoV-1. N Engl J Med. 2020 Apr
16;382(16):1564-7. doi: 10.1056/NEJMc2004973.

20. Santarpia JL, Rivera DN, Herrera V, Morwitzer MJ, Crearger H, Santarpia GW, Crown KK, Brett-Major DM, Schnaubelt E, Broadhurst MJ, Lawler JV, Reid SP, Lowe JJ. Transmission potential of SARS-CoV-2 in viral shedding observed at the University of Nebraska Medical Center. medRxiv 2020. doi: 10.1101/2020.03.23.20039446.

21. Rothe C, Schunk M, Sothmann P, Bretzel G, Froeschl G, Wallrauch C, Zimmer T, Thiel V, Janke C, Guggemos W, Seilmaier M, Drosten C, Vollmar P, Zwirglmaier K, Zange S, Wölfel R, Hoelscher M. Transmission of 2019-nCoV Infection from an Asymptomatic Contact in Germany. N Engl J Med. 2020 Mar 5;382(10):970-1. doi: 10.1056/ NEJMc2001468.

22. Yu P, Zhu J, Zhang Z, Han Y. A Familial Cluster of Infection Associated With the 2019 Novel Coronavirus Indicating Possible Person-to-Person Transmission During the Incubation Period. J Infect Dis. 2020 May 11;221(11):175761. doi: 10.1093/infdis/jiaa077.

23. Bai Y, Yao L, Wei T, Tian F, Jin DY, Chen L, Wang M. Presumed Asymptomatic Carrier Transmission of COVID-19. JAMA. 2020 Apr 14;323(14):1406-7. doi: 10.1001/jama.2020.2565.

24. Pan F, Ye T, Sun P, Gui S, Liang B, Li L, Zheng D, Wang J, Hesketh RL, Yang L, Zheng C. Time Course of Lung Changes at Chest CT during Recovery from Coronavirus Disease 2019 (COVID-19). Radiology. 2020 Jun;295(3):71521. doi: $10.1148 /$ radiol.2020200370.

25. Song C, Wang Y, Li W, Hu B, Chen G, Xia P, Wang W, Li C, Hu Z, Yang X, Yao B, Liu Y. Detection of 2019 novel coronavirus in semen and testicular biopsy specimen of COVID-19 patients. medRxiv 2020. doi: 10.1101/2020.03.31.20042333.

26. World Health Organization. WHO Director-General's opening remarks at the media briefing on COVID-19 11 March 2020. Available at: https://www.who.int/dg/ speeches/detail/who-director-general-s-opening-remarksat-the-media-briefing-on-covid-19---11-march-2020. Accessed June 30, 2020.

27. World Health Organization. COVID-19 WHOAfricaUpdate. WHO Regional Office for Africa. [As of July 9, 2020]. Available at: https://twitter.com/WHOAFRO/ status/1279770253036326918/photo/1. Accessed June 30, 2020.

28. Worldometer. Reported cases and deaths by country, territory, or conveyance. [As of July 9, 2020]. Available at: https://www.worldometers.info/. Accessed June 30, 2020. 